\title{
Peran Otoritas Jasa Keuangan pada Kredit Perbankan di Sektor Usaha Mikro, Kecil dan Menengah dalam Upaya Meningkatkan Pembangunan Nasional melalui Pengembangan Potensi Pariwisata Daerah
}

\author{
Elza Qorina Pangestika
}

Universitas Widya Mataram

\begin{abstract}
Abstrak
Bank adalah lembaga keuangan yang oleh Pemerintah diharapkan dapat menjadi roda penggerak perekonomian negara terutama terkait dengan pemberdayaan Usaha Mikro, Kecil dan Menengah dalam upaya meningkatkan pembangunan nasional melalui pengembangan potensi pariwisata daerah. Bank menyalurkan kredit kepada sektor Usaha Mikro, Kecil dan Menengah diatur dan diawasi oleh Otoritas Jasa Keuangan. Pelaksanaan penyaluran kredit yang tidak sesuai dengan ketentuan dari Otoritas Jasa Keuangan selanjutnya akan ditindaklanjuti dengan mekanisme pemberian sanksi.
\end{abstract}

Kata kunci: Perjanjian Kredit, Otoritas Jasa Keuangan, Usaha Sektor Mikro Kecil dan Menengah

\begin{abstract}
Bank is a financial institution by the government is expected to become a cog economies mainly related to the empowerment of Micro, Small and Medium Enterprises in an effort to enhance national development through developing regional tourism potential. Bank in lending to Micro, Small and Medium regulated by the Financial Services Authority. Implementation of lending, which is not accordance with the provisions of the Financial Services Authority will then be followed up with a mechanism of sanctions.
\end{abstract}

Key words: Credit Agreement, Financial Services Authority, Micro Small and Medium Enterprises 


\section{Latar Belakang}

Penjelasan Peraturan Pemerintah Republik Indonesia Nomor 50 Tahun 2011 tentang Rencana Induk Pembangunan Kepariwisataan Nasional Tahun 2010-2025 memaparkan bahwa

Indonesia merupakan negara kepulauan yang mempunyai bentang alam yang sangat indah dan memiliki banyak tempat yang dapat dikembangkan menjadi lokasi destinasi wisata, bentang alam Indonesia yang dianugerahi dengan beragam keunikan dan kontur yang menakjubkan menjadikan Indonesia memiliki potensi besar dalam kepariwisataan jika dikelola dengan baik dan benar.

Pariwisata sebagai sektor kehidupan, telah mengambil peran penting dalam pembangunan perekonomian bangsa-bangsa di dunia khususnya dalam 2 (dua) dekade terakhir, yang ditunjukkan dengan meningkatnya kesejahteraan ekonomi bangsa-bangsa di dunia yang semakin baik dan maju.

Prospek yang sangat stretegis pada sektor pariwisata dapat menjadi peluang yang sangat berarti bagi suatu negara yang memiliki kekayaan alam dan budaya yang sangat besar. Pengelolaan pariwisata yang baik dengan menitik beratkan pada sumber daya alam serta sumber daya manusia, berpotensi baik bagi pembangunan sistem perekonomian Indonesia.

Pembangunan sistem perekonomian yang melibatkan masyarakat dari semua lapisan sangat diperlukan guna menopang permasalahan ekonomi tersebut agar nantinya tujuan negara dalam menyejahterakan rakyat seperti yang termuat dalam Pembukaan Undang-Undang Dasar 1945 dapat tercapai. Pemberdayaan Sektor Usaha Mikro, Kecil, dan Menengah menjadi salah satu bentuk upaya pembangunan sistem perekonomian Indonesia yang tidak hanya menyentuh tetapi melibatkan pula lapisan masyarakat bawah, banyak menyerap tenaga kerja sehingga mengurangi jumlah pengangguran, sebagai pemasok semua kebutuhan masyarakat mulai dari kebutuhan primer hingga tersier, selain itu juga karena sektor ini terbukti mempunyai ketangguhan terhadap goncangan perekonomian global, mengingat gelombang krisis keuangan Asia 1997 tidak berimbas besar pada sektor ini (Malau, 2015). 
Keseriusan pemerintah untuk menjadikan sektor Usaha Mikro, Kecil dan Menengah sebagai roda penggerak perekonomian diwujudkan dalam sebuah peraturan perundang-undangan yaitu Undang-Undang Nomor 20 Tahun 2008 tentang Usaha Mikro, Kecil, dan Menengah. Melalui ketentuan kebijakan tersebut, Pemerintah tidak hanya mengatur mengenai pemberdayaan usaha sektor Mikro, Kecil, dan Menengah namun juga memberikan kemudahan dan dorongan untuk usaha tersebut dapat berkembang.

Pasal 2 ayat (1) Peraturan Bank Indonesia Nomor 14/22/PBI/2012 tentang Pemberian Kredit atau Pembiayaan Oleh Bank Umum dan Bantuan Teknis dalam Rangka Pengembangan Usaha Mikro, Kecil dan Menengah menguraikan bahwa

Dukungan pemerintah terhadap sektor Usaha Mikro, Kecil, dan Menengah juga disampaikan pula di dalam Peraturan Bank Indonesia yang mengatur mengenai pemberian kredit atau pembiayaan bagi sektor Usaha Mikro, Kecil dan Menengah yaitu Peraturan Bank Indonesia Nomor 14/22/PBI/2012 tentang Pemberian Kredit atau Pembiayaan Oleh Bank Umum dan Bantuan Teknis dalam Rangka Pengembangan Usaha Mikro, Kecil dan Menengah.

Dalam Peraturan Bank Indonesia Nomor 14/22/PBI/2012 tentang Pemberian Kredit atau Pembiayaan Oleh Bank Umum dan Bantuan Teknis dalam Rangka Pengembangan Usaha Mikro, Kecil dan Menengah tersebut pemerintah secara tegas memberikan instruksi kepada Bank Umum untuk memberikan kemudahan akses penyaluran kredit kepada pelaku usaha sektor Mikro, Kecil dan Menengah sebagai upaya untuk pengembangan Usaha Mikro, Kecil dan Menengah dan diharapkan jumlah pengusaha sektor ini akan semakin bertambah jumlahnya.

Prosedur administrastif pengajuan kredit yang berbelit, keharusan adanya jaminan (agunan), tingkat suku bunga yang dikenakan terhadap kredit MKM dianggap masih tinggi, dan juga permasalahan suku bunga yang sewaktu-waktu berubah tanpa pemberitahuan yang dilakukan oleh bank terhadap kredit sektor Usaha Mikro, Kecil dan Menengah secara sepihak tidak sesuai dengan sebagaimana yang diatur oleh pemerintah serta tidak sejalan dengan prinsip 
Usaha Mikro, Kecil dan Menengah. Sebagai akibatnya bagi debitur atau konsumen yang dalam hal ini adalah pelaku usaha sektor Mikro, Kecil dan Menengah mengalami kesulitan untuk mempertahankan keberlanjutan usaha dan pengembangan usahanya karena Usaha Mikro, Kecil dan Menengah dianggap kurang bankable (Sukanti, 2016). Berdasarkan uraian di atas menunjukkan bahwa implementasi dari kebijakan pemerintah yaitu Peraturan Bank Indonesia Nomor 14/22/PBI/2012 tentang Pemberian Kredit atau Pembiayaan Oleh Bank Umum dan Bantuan Teknis dalam Rangka Pengembangan Usaha Mikro, Kecil dan Menengah dan Undang-Undang Nomor 20 Tahun 2008 tentang Usaha Mikro, Kecil, dan Menengah yang digadang akan menjadi pro-MKM belum berjalan dengan baik.

Otoritas Jasa Keuangan adalah sebuah lembaga independen yang bebas dari intervensi. Dibentuk berdasarkan amanat dari Pasal 34 Undang-Undang Nomor 3 Tahun 2004 tentang Perubahan Atas Undang-Undang Nomor 23 Tahun 1999 tentang Bank Indonesia yang intinya adalah memberikan kewenangan yang terkait dengan pengaturan dan pengawasan microprudential kepada otoritas yang independen dan dilaksanakan secara terintegritas seperti tertuang dalam Pasal 55 ayat (2) Undang-Undang Nomor 21 Tahun 2011 tentang Otoritas Jasa Keuangan.

Otoritas Jasa Keuangan memiliki kewenangan untuk melakukan pengaturan dan pengawasan microprudential termasuk di dalamnya adalah pengawasan terhadap segala kegiatan usaha yang dilakukan oleh bank umum. Kegiatan usaha bank umum yang dimaksud salah satunya adalah penyaluran kredit perbankan sebagai upaya pemerataan ekonomi nasional. Otoritas Jasa Keuangan berarti secara aktif ikut berperan dalam penyaluran kredit perbankan melalui mekanisme pengaturan dan pengawasan sebagaimana fungsinya (Taqiyuddin, 2012).

Praktik penyaluran kredit perbankan terhadap sektor Usaha Mikro, Kecil, dan Menengah yang mengalami berbagai macam kendala seperti yang telah dijelaskan diatas, menunjukkan peran dari Otoritas Jasa Keuangan sebagai pengawas dirasa kurang terlihat dengan jelas dan tegas. Terbukti masih banyak 
sekali debitur kredit perbankan (pelaku usaha sektor Mikro, Kecil dan Menengah) yang mengeluhkan sulitnya untuk mendapatkan kredit modal terutama dalam hal perjanjian kredit antara bank dengan debitur yang cenderung malah merugikan (Winarni, 2006). Sehingga peran dari Otoritas Jasa Keuangan sebagai pengawas serta pengatur dalam usaha penyaluran kredit perbankan yang berkaitan dengan perlindungan debitur sebagai konsumen kurang dirasakan, yang akibatnya akan memberikan dampak yang berlawanan dengan tujuan awalnya yaitu pro-MKM (pro Usaha Mikro, Kecil dan Menengah).

Berdasarkan uraian diatas dan dilandasi dengan pemikiran bahwa sangat penting untuk diketahui bagaimana peranan Otoritas Jasa Keuangan pada kredit perbankan di sektor Usaha Mikro, Kecil dan Menengah dalam upaya meningkatkan pembangunan nasional melalui pengembangan potensi pariwisata daerah?

\section{Hasil Penelitian dan Pembahasan}

Pengelolaan pariwisata merupakan pengelolaan berbagai macam kegiatan wisata dan didukung berbagai fasilitas serta layanan yang disediakan yang oleh masyarakat, pengusaha, pemerintah, dan pemerintah daerah. Pengelolaan pariwisata dapat meliputi berbagai kegiatan yang berhubungan dengan objek wisata, daya tarik wisata, pengusaha, serta usaha lainnya yang terkait. Pengelolaan pariwisata dimaksudkan agar daya tarik pariwisata dapat didayagunakan secara optimal, namun dengan tetap menjaga keutuhan dan keasliannya. Salah satu dukungan dalam pengelolaan pariwisata ini adalah melalui Usaha Mikro, Kecil dan Menengah.

Dalam Peraturan Presiden Nomor 2 Tahun 2015 tentang Rencana Pembangunan Jangka Menengah Nasional 2015-2019 disebutkan bahwa "Salah satu sasaran penguatan sektor keuangan dalam lima tahun mendatang yaitu meningkatnya akses masyarakat dan Usaha Mikro, Kecil dan Menengah terhadap layanan jasa keuangan formal dalam kerangka pembangunan ekonomi yang inklusif dan berkeadilan". Dalam rangka implementasi peningkatan keuangan inklusif di Indonesia, maka pemerintah mengeluarkan Peraturan 
Presiden Nomor 82 Tahun 2016 tentang Strategi Nasional Keuangan Inklusif di Indonesia yang dijabarkan pada lampirannya bahwa "Salah satu sasaran peningkatan keuangan inklusif di Indonesia adalah pelaku usaha mikro dan kecil".

Kegiatan bisnis skala Mikro, Kecil dan Menengah memiliki peran penting dalam mendukung pengembangan potensi wisata di suatu daerah sekaligus mendukung kehidupan ekonomi rumah tangga miskin. Usaha Mikro, Kecil dan Menengah berpotensi menurunkan tingkat kemiskinan karena kegiatan bisnis ini mampu meningkatkan nilai tambah yang diterima oleh rumah tangga miskin, baik dalam bentuk upah maupun profitabilitas (Nugroho, 2016).

Untuk memperkuat permodalan kepada Usaha Mikro, Kecil dan Menengah, pemerintah dan Bank Indonesia telah membuat beberapa kebijakan agar pihak perbankan dapat memperbesar prosi kredit Usaha Mikro, Kecil dan Menengah dari total kredit yang disalurkannya. Bank Indonesia mengeluarkan Peraturan Bank Indonesia Nomor 14/22/PBI/2012 tentang Pemberian Kredit atau Pembiayaan Oleh Bank Umum dan Bantuan Teknis dalam Rangka Pengembangan Usaha Mikro, Kecil dan Menengah sebagaimana dirubah oleh Peraturan Bank Indonesia Nomor 17/12/PBI/2015 tentang Pemberian Kredit atau Pembiayaan oleh Bank Umum dan Bantuan Teknis dalam rangka Pengembangan Usaha Mikro, Kecil dan Menengah. Dalam Peraturan Bank Indonesia tersebut, kredit atau pembiayaan yang dilakukan oleh bank harus disalurkan kepada Usaha Mikro, Kecil dan Menengah secara bertahap hingga mencapai 20\% pada tahun 2018. Jumlah kredit atau pembiayaan Usaha Mikro, Kecil dan Menengah yang ditetapkan paling rendah 20\% yang dihitung berdasarkan rasio kredit atau pembiayaan Usaha Mikro, Kecil dan Menengah terhadap total kredit atau pembiayaan dengan pemenuhan secara bertahap yaitu:

1) Tahun 2013 dan 2014, rasio kredit Usaha Mikro, Kecil dan Menengah ditetapkan sesuai kemampuan bank;

2) Tahun 2015, rasio kredit Usaha Mikro, Kecil dan Menengah ditetapkan paling rendah $5 \%$; 
3) Tahun 2016, rasio kredit Usaha Mikro, Kecil dan Menengah terhadap total kredit ditetapkan paling rendah $10 \%$;

4) Tahun 2017, rasio kredit Usaha Mikro, Kecil dan Menengah ditetapkan paling rendah $15 \%$;

5) Tahun 2018, rasio kredit Usaha Mikro, Kecil dan Menengah ditetapkan paling rendah $20 \%$.

Salah satu masalah klasik yang dihadapi oleh Usaha Mikro, Kecil dan Menengah adalah keterbatasan akses pada kredit perbankan. Perbankan besar enggan menyalurkan kredit skala kecil kepada Usaha Mikro, Kecil dan Menengah karena beberapa faktor, diantaranya:

1) Tingginya biaya dan risiko kredit macet yang dihadapi oleh bank dalam penyaluran kredit skala kecil. Misalnya kredit sebesar Rp 1.000.000.000,00 kepada salah satu usaha menengah dan besar memiliki biaya rata-rata yang jauh lebih kecil dibandingkan bila kredit tersebut disalurkan kepada 100 usaha mikro dan kecil dengan nilai kredit masing-masing sebesar Rp 10.000.000,00. Singkatnya tingginya biaya rata-rata pengelolaan per unit kredit skala kecil ini menyebabkan perbankan enggan menyalurkan kredit kepada Usaha Mikro, Kecil dan Menengah;

2) Tingginya risiko kemacetan (risk of loan default) dari kredit skala kecil lantaran Usaha Mikro, Kecil dan Menengah tidak memiliki sistem akuntansi yang baik sehingga menyulitkan perbankan dalam menilai kelayakan Usaha Mikro, Kecil dan Menengah. Usaha Mikro, Kecil dan Menengah dengan jumlah yang sangat banyak dan karakteristik beragam, baik dari sisi jeniss usaha (heterogenous), skala usaha, pengalaman bisnis, maupun kemampuan manajerial dan teknologi produksi membuat bank menghadapi kesulitan dalam menilai kelayakan usaha dan prospek bisnis Usaha Mikro, Kecil dan Menengah. Masalah informasi ini menyebabkan bank enggan memberikan pelayanan kepada Usaha Mikro, Kecil dan Menengah;

3) Ketiadaan sistem penjaminan kredit skala kecil. Pada saat sistem jaminan tidak berkembang, bank akan menilai kelayakan kredit Usaha Mikro, Kecil dan Menengahhanya dari sisi kemampuannya dalam menyediakan agunan 
kredit yang memadai. Konsekuensinya, ketidakmampuan Usaha Mikro, Kecil dan Menengah menyediakan agunan kredit menyebabkan bank enggan menyalurkan kredit kepada Usaha Mikro, Kecil dan Menengah. Hal ini terjadi dikarenakan bank tidak memiliki kekuatan (enforcement tool) untuk mendorong Usaha Mikro, Kecil dan Menengah mengembalikan kredit yang telah disalurkan. Bank akan cenderung selektif dan membatasi kredit yang akan diberikan kepada Usaha Mikro, Kecil dan Menengah. Bank hanya akan menyalurkan kredit kepada Usaha Mikro, Kecil dan Menengah yang layak dan prospektif serta cenderung mengabaikan Usaha Mikro, Kecil dan Menengah yang dinilainya tidak prospektif.

4) Bank memiliki keterbatasan operasional dalam melayani kredit skala kecil kepada Usaha Mikro, Kecil dan Menengah karena mereka harus tunduk kepada ketentuan-ketentuan otoritas perbankan. Misalnya ketentuan tentang keharusan adanya agunan menyebabkan bank hanya akan melayani Usaha Mikro, Kecil dan Menengah (Nugroho, 2016).

Untuk memperbesar akses permodalan bagi pelaku Usaha Mikro, Kecil dan Menengah agar tidak hanya kepada pihak perbankan saja, dalam Pasal 21 UndangUndang Nomor 20 Tahun 2008 tentang Usaha Mikro, Kecil, dan Menengah menegaskan peran pemerintah dan usaha besar untuk membantu pendanaan Usaha Mikro, Kecil dan Menengah, seperti : 1.Pemerintah (termasuk pemerintah daerah) menyediakan pembiayaan bagi Usaha Mikro, Kecil dan Menengah; 2.BUMN dapat menyediakan pembiayaan dari penyisihan bagian laba tahunan yang dialokasikan kepada Usaha Mikro, Kecil dan Menengah dalam bentuk pemberian pinjaman, penjaminan, hibah, dan pembiayaan lainnya; 3.Usaha besar (termasuk perusahaan asing di Indonesia) dapat menyediakan pembiayaan untuk Usaha Mikro, Kecil dan Menengah; 4.Pemerintah (termasuk pemerintah daerah) dan usaha besar dapat memberikan hibah, mengusahakan bantuan luar negeri, dan mengusahakan sumber pembiayaan lain yang sah serta tidak mengikat untuk Usaha Mikro, Kecil dan Menengah; 5.Pemerintah (pusat maupun daerah) dapat memberikan insentif dalam bentuk kemudahan persyaratan, perizinan, keringanan tarif sarana dan prasarana, dan bentuk insentif 
lainnya yang sesuai dengan ketentuan peraturan perundang-undangan kepada usaha besar yang menyediakan pembiayaan bagi Usaha Mikro, Kecil dan Menengah (Tambunan, 2012).

Otoritas Jasa Keuangan sebagai lembaga yang mengatur, mengawasi dan melindungi keseluruhan kegiatan dalam sektor jasa keuangan tentu memiliki peran penting dalam peningkatan keuangan inklusif bagi pelaku Usaha Mikro, Kecil dan Menengah di Indonesia. Adanya akses terhadap produk dan layanan jasa keuangan merupakan hak dasar bagi seluruh masyarakat dan menjadi sangat penting dalam meningkatkan taraf hidup masyarakat menengah bawah sangat diperlukan agar mereka dapat memperoleh akses terhadap produk dan jasa keuangan. Ketersediaan layanan jasa keuangan khususnya yang berskala mikro dan membantu masyarakat ekonomi menengah bawah dalam meningkatkan kualitas hidup melalui pemanfaatan produk keuangan seperti kredit usaha berskala mikro atau tabungan untuk berinvestasi dalam bentuk asset produktif (Otoritas Jasa Keuangan \& Kementerian Dalam Negeri, 2016).

Otoritas Jasa Keuangan dalam menjalankan fungsi, tugas dan wewenangnya dalam melakukan pengawasan sistem perbankan sesuai dengan ketentuan yang tercantum dalam Undang-Undang Nomor 21 Tahun 2011 tentang Otoritas Jasa Keuangan. Otoritas Jasa Keuangan bersifat independen dan bebas dari campur tangan pihak lain yang mempunyai fungsi, tugas, dan wewenang pengaturan, pengawasan, pemeriksaan, dan penyidikan yang luas di sektor perbankan.

Mekanisme pengawasan Otoritas Jasa Keuangan telah dijabarkan dalam Pasal 7 Undang-Undang Nomor 21 Tahun 2011 tentang Otoritas Jasa Keuangan yaitu bahwa pengaturan dan pengawasan mengenai kelembagaan, kesehatan, aspek kehati-hatian, dan pemeriksaan bank merupakan lingkup pengaturan dan pengawasan microprudential yang menjadi tugas dan wewenang Otoritas Jasa Keuangan. Sesuai dengan ketentuan dalam Pasal 7 Undang-Undang Nomor 21 Tahun 2011 tentang Otoritas Jasa Keuangan, Otoritas Jasa Keuangan membuat pengaturan dan melakukan pengawasan mengenai aspek kehati-hatian bank, meliputi : manajemen resiko; tata kelola bank; prinsip mengenal nasabah dan 
anti pencucian uang; dan pencegahan pembiayaan terorisme dan kejahatan perbankan; serta melakukan pemeriksaan bank secara berkala.

Pengaturan dan pengawasan yang dilakukan oleh Otoritas Jasa Keuangan terhadap produk-produk yang dikeluarkan bank, diarahkan untuk mengoptimalkan fungsi perbankan Indonesia dalam hal sebagai berikut :

1) Sebuah lembaga kepercayaan masyarakat dalam kaitannya sebagai lembaga penghimpun dan penyalur dana;

2) Pelaksana kebijakan moneter;

3) Lembaga yang ikut berperan dalam membantu pertumbuhan ekonomi serta pemerataan agar dapat terciptanya sistem perbankan yang baik dan sehat. Untuk mencapai tujuan tersebut, pendekatan yang dilakukan oleh Otoritas Jasa Keuangan adalah dengan menerapkan : (Sigalingging, 2011)

1) Kebijakan memberikan keleluasaan berusaha (deregulasi);

2) Kebijakan prinsip kehati-hatian bank (prudential bank);

3) Pengawasan bank yang mendorong bank untuk melaksanakan secara konsisten ketentuan internal yang dibuat sendiri (self regulatory banking) dalam melaksanakan kegiatan operasionalnya dengan tetap mengacu kepada prinsip kehati-hatian.

Dengan semakin berkembangnya jaman, produk-produk yang dikeluarkan oleh bank semakin beragam namun tidak diiringi dengan sosialisasi secara maksimal kepada masyarakat, sehingga tidak jarang masih terdapat masyarakat yang mengeluh mengenai produk-produk tersebut. Hubungan yang terjalin antara bank dengan nasabahnya didasarkan pada prinsip kepercayaan, akan tetapi dalam praktiknya seringkali tidak dapat dihindarkan adanya sengketa (dispute) antara nasabah dengan pihak bank. Hal tersebut pada umumnya berawal dengan terjadinya complain yang diajukan pihak nasabah kepada bank karena merasa dirugikan secara finansial. Salah satu produk perbankan yang sering menuai masalah adalah kredit. 


\section{Kesimpulan}

Otoritas jasa Keuangan telah berperan dengan sangat baik, sesuai dengan peraturan perundang-undangan yang berlaku dalam pengawasan pemberian kredit perbankan di sektor Usaha Mikro, Kecil dan Menengah dalam upaya meningkatkan pembangunan nasional melalui pengembangan potensi pariwisata daerah.

\section{Saran}

Perlunya sosialisasi kepada masyarakat mengenai peran dari lembaga Otoritas Jasa Keuangan dalam perjanjian kredit perbankan pada sektor Usaha Mikro, Kecil dan Menengah dalam upaya meningkatkan pembangunan nasional melalui pengembangan potensi pariwisata daerah.

\section{Daftar Referensi}

\section{Buku-Buku}

Badrulzaman, Mariam Darus. (1980). Perjanjian Kredit Bank. Bandung: Alumni.

Gazali, Djoni S., \& Usman, Rachman. (2010). Hukum Perbankan. Jakarta: Sinar Grafika.

Hermansyah. (2007). Hukum Perbankan Nasional Indonesia (2 ${ }^{\text {nd }}$ ed.). Jakarta: Kencana.

Hermansyah. (2005). Hukum Perbankan Nasional Indonesia. Jakarta: Prenada Media.

Ibrahim, Johannes. (2004). Bank sebagai Lembaga Intermediasi dalam Hukum Positif. Bandung: CV.Utomo.

Idroes, Fery N. (2006). Manajemen Risiko Perbankan Dalam Konteks Kesepakatan Basel dan Peraturan Bank Indonesia. Yogyakarta: Graha Ilmu. 
Muta'ali, Lutfi. (2012). Daya Dukung Lingkungan untuk Perencanaan Pengembangan Wilayah. Yogyakarta: Badan Penerbit Fakultas Geografi UGM.

Nugroho, Agus Eko. (2016). Komersialisasi Kredit Program Untuk Pengembangan UMKM dan Penanggulangan Kemiskinan dalam Buku Komesialisme Kredit Usaha Rakyat Untuk Pemberdayaan UMKM di Indonesia. Jakarta: LIPI Press.

Otoritas Jasa Keuangan \& Kementerian Dalam Negeri. (2016). Buku Pedoman Tim Percepatan Akses Keuangan Daerah, Jakarta: -

Siamat, Dahlan. (2005). Manajemen Lembaga Keuangan: Kebijakan Moneter dan Perbankan (5 $5^{\text {th }}$ ed.). Jakarta: Lembaga Penerbit Fakultas Ekonomi Universitas Indonesia.

Sigalingging, Bisdan. (2011). Tugas dan Kewenangan Otoritas Jasa Keuangan dan Bank Indonesia Menurut Undang-Undang Otoritas Jasa Keuangan. Jakarta: Gramedia.

Soekadijo. (1997). Anatomi Pariwisata: Memahami Pariwisata sebagai Systemic Linkage. Jakarta: PT. Gramedia Pustaka Utama.

Suhardi, Gunarto. (2003). Usaha Perbankan dalam Perspektif Hukum. Yogyakarta: Kanisius.

Sutarno. (2005). Aspek-Aspek Hukum Perkreditan pada Bank. Bandung: Alfabeta.

Tambunan, Tulus. (2012). Usaha Mikro Kecil dan Menengah di Indonesia: Isu-Isu Penting. Jakarta: LP3ES.

Tohar, M. (1999). Pemodalan dan Perkreditan Koperasi. Yogyakarta: Kanisius.

Usman, Rachmadi. (2001). Aspek-Aspek Hukum Perbankan di Indonesia. Jakarta: PT. Gramedia Pustaka Utama.

Wahab, Salah. (1992). Manajemen Pariwisata. Bandung: Angkasa. 
Garner, Bryan. (2014). Black's Law Dictionary $\left(10^{\text {th }}\right.$ ed). Amerika: Thomson West.

Malau, Masnur Tiurmaida. (2015). Aspek Hukum Peraturan dan Kebijakan Pemerintah Indonesia Menghadapi Liberalisasi Ekonomi Regional: Masyarakat Ekonomi ASEAN 2015. Jurnal Rechts Vinding, 3, 167.

Winarni, Endang Sri. (2006). Strategi Pengembangan Usaha Kecil Melalui Peningkatan Aksesibilitas Kredit Perbankan. Infokop, 29, 92.

Anugrah, M. Lazuardhi Redha. (2017). Penerapan Perlindungan Rahasia Bank terhadap Nasabah Studi Kasus di PT. Bank Negara Indonesia (Persero) Tbk. Gadjah Mada University, Thesis. http://www.lib.ugm.ac.id/

Sukanti, Adityastiti Rahmi. (2016). Peran Otoritas Jasa Keuangan dalam Perjanjian Kredit Perbankan pada Sektor Usaha Mikro, Kecil, dan Menengah di PT Bank Rakyat Indonesia (Persero) Tbk Kantor Cabang Semarang Barat. Gadjah Mada University, Thesis. http://www.lib.ugm.ac.id/

Taqiyuddin, Ahmad. (2012). Undang-Undang OJK dalam Kajian Hukum dan Pembangunan Ekonomi. Lambung Mangkurat University, Thesis. http://lib.ulm.ac.id/

\section{Peraturan Perundang-undangan}

Undang-Undang Dasar Negara Republik Indonesia Tahun 1945.

Kitab Undang-Undang Hukum Perdata.

Undang-Undang Nomor 10 Tahun 1998 tentang Perubahan Atas Undang-Undang Nomor 7 Tahun 1992 tentang Perbankan (Lembaran Negara Republik Indonesia Tahun 1998 Nomor 182, Tambahan Lembaran Negara Republik Indonesia Nomor 3790). 
Undang-Undang Nomor 8 Tahun 1999 tentang Perlindungan Konsumen (Lembaran Negara Republik Indonesia Tahun 1999 Nomor 42, Tambahan Lembaran Negara Republik Indonesia Nomor 3821).

Undang-Undang Nomor 3 Tahun 2004 tentang Perubahan Atas UndangUndang Nomor 23 Tahun 1999 tentang Bank Indonesia (Lembaran Negara Republik Indonesia Tahun 2004 Nomor 7).

Undang-Undang Nomor 10 Tahun 2009 tentang Kepariwisataan (Lembaran Negara Republik Indonesia Tahun 2009 Nomor 11, Tambahan Lembaran Negara Republik Indonesia Nomor 4966).

Undang-Undang Nomor 21 Tahun 2011 tentang Otoritas Jasa Keuangan (Lembaran Negara Republik Indonesia Tahun 2011 Nomor 111, Tambahan Lembaran Negara Republik Indonesia Nomor 5253.

Peraturan Presiden Nomor 2 Tahun 2015 tentang Rencana Pembangunan Jangka Menengah Nasional 2015-2019 (Lembaran Negara Republik Indonesia Tahun 2015 Nomor 3).

Peraturan Presiden Nomor 82 Tahun 2016 tentang Strategi Nasional Keuangan Inklusif di Indonesia (Lembaran Negara Republik Indonesia Tahun 2016 Nomor 185).

Peraturan Pemerintah Republik Indonesia Nomor 50 Tahun 2011 tentang Rencana Induk Pembangunan Kepariwisataan Nasional Tahun 20102025 (Lembaran Negara Republik Indonesia Tahun 2011 Nomor 125; Tambahan Lembaran Negara Republik Indonesia Nomor 5262)

Peraturan Pemerintah Nomor 17 Tahun 2013 tentang Pelaksanaan Undang-Undang Nomor 2008 tentang Usaha Mikro Kecil dan Menengah (Lembaran Negara Republik Indonesia Tahun 2013 Nomor 40; Tambahan Lembaran Negara Republik Indonesia Nomor 5404).

Peraturan Menteri Keuangan Nomor 135/PMK.05/2008 tentang Fasilitas Penjaminan Kredit Usaha Rakyat yang sebagaimana telah diubah 
dengan Peraturan Menteri Keuangan No. 22/PMK.05/2010

(Lembaran Negara Republik Indonesia Tahun 2010 Nomor 46).

Peraturan Menteri Koordinator Bidang Perekonomian Republik

Indonesia selaku Ketua Komite Kebijakan Pembiayaan Bagi Usaha Mikro, Kecil dan Menengah Nomor 13 Tahun 2015 tentang Perubahan Atas Peraturan Menteri Koordinator Bidang Perekonomian selaku Ketua Komite Kebijakan Pembiayaan Bagi Usaha Mikro, Kecil dan Menengah Nomor 8 Tahun 2015 tentang Pedoman Pelaksanaan Kredit Usaha Rakyat (Lembaran Berita Negara Republik Indonesia Tahun 2016 Nomor 48).

Peraturan Bank Indonesia Nomor 14/22/PBI/2012 tentang Pemberian Kredit atau Pembiayaan oleh Bank Umum dan Bantuan Teknis dalam Rangka Pengembangan UMKM (Lembaran Negara Republik Indonesia Tahun 2012 Nomor 274 DKBU, Tambahan Lembaran Negara Republik Indonesia Nomor 5378).

Peraturan Bank Indonesia Nomor 17/12/PBI/2015 tentang Pemberian Kredit atau Pembiayaan oleh Bank Umum dan Bantuan Teknis dalam rangka Pengembangan Usaha Mikro, Kecil dan Menengah (Lembaran Negara Republik Indonesia Tahun 2012 Nomor 274, Tambahan Lembaran Negara Republik Indonesia Nomor 5378)

Peraturan Otoritas Jasa Keuangan Nomor 1/POJK.07/2013 tentang Perlindungan Konsumen Sektor Jasa Keuangan (Lembaran Negara Republik Indonesia Tahun 2013 Nomor 118, Tambahan Lembaran Negara Republik Indonesia Nomor 5431). 